\title{
Novel immortalized human fetal liver cell line, cBAL I I , has the potential to differentiate into functional hepatocytes
} Tanja Deurholt ${ }^{1}$, Niek P van Til ${ }^{1}$, Aniska A Chhatta ${ }^{1}$, Lysbeth ten Bloemendaal ${ }^{1,2}$, Ruth Schwartlander ${ }^{3}$, Catherine Payne ${ }^{4}$, John N Plevris ${ }^{4}$, Igor M Sauer ${ }^{3}$, Robert AFM Chamuleau ${ }^{1}$, Ronald PJ Oude Elferink ${ }^{1}$, Jurgen Seppen ${ }^{1}$ and Ruurdtje Hoekstra*1,2

Address: ${ }^{1}$ AMC Liver Center, Meibergdreef 69-71, 1105 BK Amsterdam, the Netherlands, ${ }^{2}$ Department. of Surgery (Surgical Laboratory), Academic Medical Center, Meibergdreef 9, 1105 AZ Amsterdam, the Netherlands, ${ }^{3}$ Experimental Surgery and Regenerative Medicine, Charité, Augustenburger Platz 1, 13353 Berlin, Germany and ${ }^{4}$ Department of Hepatology, Royal Infirmary of Edinburgh, 49 Little France crescent, Edinburgh EH16 4SB, UK

Email: Tanja Deurholt - tanjadeurholt@gmail.com; Niek P van Til - n.vantil@erasmusmc.nl; Aniska A Chhatta - A.A.Chhatta@amc.uva.nl; Lysbeth ten Bloemendaal - l.tenbloemendaal@amc.uva.nl; Ruth Schwartlander - ruth.schwartlander@charite.de; Catherine Payne - catherine.payne@ed.ac.uk; John N Plevris - J.Plevris@ed.ac.uk; Igor M Sauer - igor.sauer@charite.de; Robert AFM Chamuleau - r.a.chamuleau@amc.uva.nl; Ronald PJ Oude Elferink - R.P.Oude-Elferink@amc.uva.nl; Jurgen Seppen - J.Seppen@amc.uva.nl; Ruurdtje Hoekstra* - R.Hoekstra@amc.uva.nl

* Corresponding author

Published: 21 October 2009

BMC Biotechnology 2009, 9:89 doi:10.1 186/1472-6750-9-89
Received: 23 September 2008

Accepted: 21 October 2009

This article is available from: http://www.biomedcentral.com/I472-6750/9/89

(C) 2009 Deurholt et al; licensee BioMed Central Ltd.

This is an Open Access article distributed under the terms of the Creative Commons Attribution License (http://creativecommons.org/licenses/by/2.0), which permits unrestricted use, distribution, and reproduction in any medium, provided the original work is properly cited.

\begin{abstract}
Background: A clonal cell line that combines both stable hepatic function and proliferation capacity is desirable for in vitro applications that depend on hepatic function, such as pharmacological or toxicological assays and bioartificial liver systems. Here we describe the generation and characterization of a clonal human cell line for in vitro hepatocyte applications.
\end{abstract}

Results: Cell clones derived from human fetal liver cells were immortalized by over-expression of telomerase reverse transcriptase. The resulting cell line, cBALIII, displayed hepatic functionality similar to the parental cells prior to immortalization, and did not grow in soft agar. Cell line CBALIII expressed markers of immature hepatocytes, like glutathione $S$ transferase and cytokeratin 19, as well as progenitor cell marker CDI46 and was negative for lidocaine elimination. On the other hand, the CBALI I I cells produced urea, albumin and cytokeratin 18 and eliminated galactose. In contrast to hepatic cell lines NKNT-3 and HepG2, all hepatic functions were expressed in CBALIII, although there was considerable variation in their levels compared with primary mature hepatocytes. When transplanted in the spleen of immunodeficient mice, CBALI I I engrafted into the liver and partly differentiated into hepatocytes showing expression of human albumin and carbamoylphosphate synthetase without signs of cell fusion.

Conclusion: This novel liver cell line has the potential to differentiate into mature hepatocytes to be used for in vitro hepatocyte applications. 


\section{Background}

Most pharmacological or toxicological assays and bioartificial liver support systems require fully differentiated hepatocytes. The availability of mature human hepatocytes is variable and the numbers low, because they are usually isolated from donor livers not suitable for transplantation. In addition these cells hardly proliferate in vitro $[1,2]$. Since mature human hepatocytes cannot be used for large-scale applications, there is a pressing need for a cell line that combines highly differentiated hepatic functions while maintaining adequate proliferation capacity.

Several cell lines derived from human liver tumours, such as the hepatoma cell line HepG2 [3], as well as in vitro immortalized cell lines, like the NKNT-3 cell line, have been investigated $[4,5]$. In general, these cell lines proliferate adequately, but the levels of hepatocyte-specific functions (e.g. urea production from ammonia and cytochrome 4450 detoxification activity) remain disappointedly low.

In tumour-derived cell lines, the mutations leading to immortalization are largely unknown. In an attempt to control the immortalization process and therefore prevent at least part of the dedifferentiation process, several immortalized cell lines have been developed. However, although certain genetic modifications in immortalized cell lines are known, spontaneous mutations contributing to the immortalization cannot be excluded.

For successful in vitro immortalization, overexpression of cell cycle stimulating genes is generally required. Due to the low proliferation capacity of mature hepatocytes, strong stimulation of cell cycle progression is necessary for immortalization. In the majority of in vitro immortalizations of primary human liver cells, the gene encoding Simian Virus 40 Large T antigen (SV40T), an inhibitor of the cell cycle inhibitors p53 and the Retinoblastoma protein, has been used [4,6-8]. In addition, overexpression of Cyclin D1, which stimulates cell cycle progression, and dominant negative mutants of p53 have also led to successful immortalization [9]. In some immortalized cell lines, proliferation was combined with stabilisation of the telomeres [10]. Critically short telomeres induce a terminal state of growth arrest called crisis [11]. Overexpression of the reverse transcriptase of telomerase, hTERT, stabilizes telomere length, thereby avoiding cellular crisis. As a general principle immortalization by overexpression of hTERT only, minimises the reduction in functionality [12].

In contrast to mature human hepatocytes, fetal human hepatocytes have the ability to proliferate in vitro $[13,12]$ and thereby can be immortalized without cell cycle stimulation. In addition, telomere stabilisation in itself can immortalize these cells [12]. Wege et al showed that the immortalization of fetal human hepatocytes did not affect their differentiation potential, however, the functionality of the immortalized cells was not compared with mature human hepatocytes. Such comparison is essential to establish the suitability of these cells for hepatocyte applications in vitro. Furthermore phenotypical stability of these cells may be low, since these were not of clonal origin. In our previous report we demonstrated that primary human fetal liver cells (HFLCs) in culture exhibit albumin production rates and hepatocyte specific mRNA levels comparable to those of primary mature human hepatocytes in vitro [14]. However, after eight population doublings most of these functions were decreased to less than $1 \%$ of the corresponding function of primary human hepatocytes in vitro. This functional loss can be, at least partly, attributed to the presence of non-parenchymal cells in the cell preparation, which eventually outnumber the functional hepatocytes. Therefore, selection of functional cell clones is necessary if HFLCs are extensively expanded in vitro.

In a previous study we already isolated HFLCs and selected specific clones based on their morphology and growth potential [14]. This study combines the telomerase based immortalization technique with the selection of functional HFLCs to obtain new hepatic cell lines. The resulting immortalized cell line was tested for hepatic functionality in vitro and in vivo. The in vitro functionality was compared with other well-known hepatic cell lines, more specifically the conditionally immortalized NKNT-3 [4] and the tumour derived HepG2 cells [3]. To test whether the resulted novel immortalized cell line had the ability to differentiate into functional hepatocytes, the cell line was transplanted into the spleen of immunodeficient mice.

\section{Methods \\ Cell isolation and culture}

Human fetal livers were obtained from elective abortions. Gestational age was determined by ultrasonic measurement of the diameter of the skull and ranged from 14 to 18 weeks. The use of this tissue was approved by the Medical Ethical Committee of the Academic Medical Center, Amsterdam, the Netherlands, subject to informed patient consent in compliance with the Helsinki Declaration. We isolated HFLCs on three independent occasions; in each case four fetal livers were pooled. Cells were isolated as described previously [14]. HFLCs were seeded in DMEM culture medium (Dulbecco's modified Eagle's medium, BioWhittaker) containing $10 \%$ heat-inactivated fetal bovine serum (HI-FBS, BioWhittaker), $2 \mathrm{mM}$ L-glutamine (BioWhittaker), $1 \mu \mathrm{M}$ dexamethason (Sigma), $10 \mu \mathrm{g} / \mathrm{mL}$ insulin, $5.5 \mu \mathrm{g} / \mathrm{mL}$ transferrin, $6.7 \mathrm{ng} / \mathrm{mL}$ selenium-X (ITS mix, Life Technology), $100 \mathrm{U} / \mathrm{mL}$ penicillin, $100 \mu \mathrm{g} / \mathrm{mL}$ 
streptomycin (penicillin/streptomycin mix, BioWhittaker) at a density of approximately $3^{*} 10^{5} \mathrm{cells} / \mathrm{cm}^{2}$ in Primaria 6-well plates (BD Falcon). Clonal derivatives were obtained by limiting dilution. The selection procedure used and the functionality of the clonal derivatives are described elsewhere [14]. Near-confluent cultures were detached by 5 min incubation with $0.25 \%$ trypsin/0.03\% EDTA (BioWhittaker) and split at 1:4 ratios. The number of population doublings (PD) was calculated as $\mathrm{PD}=\log$ $\left(\mathrm{N}_{\mathrm{f}} / \mathrm{N}_{\mathrm{i}}\right) / \log 2$, in which $\mathrm{N}_{\mathrm{f}}$ is the final number of cells harvested and $\mathrm{N}_{\mathrm{i}}$ is the number of cells initially seeded. No corrections were made for cells that did not re-attach after passaging, since their proportion was negligible. The period in which PD number progressed linear with culture time was used to calculate the PD time $\left(\mathrm{T}_{\mathrm{PD}}\right)$.

Mature primary human hepatocytes were isolated from seven patients undergoing partial hepatectomy, because of metastatic carcinoma. The tumour free liver tissue used in each case for the hepatocyte isolation ranged between 2 to 10 grams. The procedure was approved by the Medical Ethical Committee of the Academic Medical Center subject to informed patient consent. The hepatocyte isolation method was adapted from the protocol described by Seglen [15] as previously described [14].

NKNT-3 cells were kindly donated by Prof. I. Fox, University of Nebraska, USA. The NKNT-3 cells were cultured on Primaria 6-well culture plates (BD Falcon) and in $75 \mathrm{~cm} 2$ culture flasks using CS-C complete serum free medium (Cell Systems Corporation) with $0.2 \mathrm{mg} / \mathrm{ml}$ hygromycin B (Invitrogen) and $1 \mathrm{U} / \mathrm{ml}$ penicillin/streptomycin (BioWhittaker). Cultures were passaged with a split ratio of 1:5 according to instructions for CS-C medium. Cre-mediated recombination to revert immortalization of NKNT-3 cells [4] was carried out by transduction of the adenoviral vector AxCANCre (Riken DNA Bank (Tsukuba Life Science Center, Japan) as described previously [5]. We analysed both reverted, hence transduced with AxCANCre and selected with G418, and unreverted i.e. untreated cells. HepG2 cells were obtained from ATCC (HB-8065) and cultured in Primaria tissue culture flasks in DMEM culture medium as described above for HFLCs.

All cultures were maintained at $37^{\circ} \mathrm{C}$ in a humidified atmosphere (95\% air, 5\% CO2) and the medium was changed every 2-3 days.

\section{Introduction of hTERT and Green Fluorescent Protein genes}

The cDNA of the human telomerase reverse transcriptase (hTERT) gene, kindly provided by R.L. Beijersbergen, Netherlands Cancer Institute, the Netherlands, was introduced in the cells by lentiviral transduction. The lentiviral vector backbone was described as LTRCMVR2 by Marcusic et al. [16]. The lentiviral vector contained a cytomegalovirus promoter controlling the expression of a reverse tetracycline (Tet) responsive transcriptional activator and a Tet responsive element controlling the expression of the hTERT gene. In this system hTERT transcription can be increased by adding $1 \mu \mathrm{g} / \mathrm{mL}$ doxycyclin to the medium.

The lentivirus was produced as previously described [17]. In brief, HEK293T cells were transiently transfected by calcium phosphate precipitation with a third generation lentiviral vector system. Virus containing supernatant was collected at 24 and 48 hours following transfection, filtered through $0.45 \mu \mathrm{m}$ Millipore filters, then 100-fold concentrated by centrifugation and added to the culture medium of the HFLCs in 24-well culture plates in a 1:50 (lentivirus preparation:culture medium) ratio. The hTERT lentivirus was introduced in three independent HFLC cultures and in five clonal derivatives, i.e. cBAL08, cBAL09, cBAL20, cBAL21 and cBAL29. Cells were passaged twice before integration of the lentiviral vector was confirmed by PCR using genomic DNA of transduced cells as template.

In the transplantation experiment cBAL111 cells were marked with Green Fluorescent Protein (GFP) by transduction using lentiviral construct pRRLcpptPGKGFPpreSsin [17] carrying the GFP gene under control of a phosphoglycerate kinase promoter. By fluorescence-activated cell sorting it was demonstrated that $\geq 95 \%$ of the transduced cells were GFP positive. There were at least five passages between transduction with GFP and transplantation of the cells. The GFP positivity, ratio as well as expression level, of the cells remained unchanged during passaging.

\section{Flow cytometry}

The cBAL111 cells, cultured for 15 days, were analyzed for progenitor cell markers by flow cytometry. For comparison HepG2 cells were included in the experiment. The cells were detached using accutase (Innovative Cell Technologies, Inc., USA), washed twice in DMEM culture medium, resuspended in $100 \mu \mathrm{l}$ DMEM and incubated for 30 minutes on ice in the dark with $10 \mu \mathrm{l}$ of the following antibodies: 1. a combination of mouse-anti human CD34-FITC and mouse-anti human CD326 (EpCAM)APC (both Miltenyi Biotech Inc.); 2. a combination of mouse-anti human CD146-FITC (Miltenyi Biotech Inc., USA) and mouse-anti human CD326 (EpCAM)-APC; 3. mouse-anti human CD133 (Miltenyi Biotech Inc., USA). The cells incubated with the CD133 antibodies were washed in culture medium and subsequently incubated with the secondary antibody goat-anti mouse IgG-Alexa fluor 488 (Molecular Probes Invitrogen, USA). As negative controls, cells were incubated with either a combination of mouse IgG2a-APC and mouse IgG1-FITC (isotype con- 
trols) (both eBioscience, USA) or with goat-anti mouse IgG-Alexa fluor 488. The cells were analyzed by flow cytometry using BD FACScalibur (BD Biosciences, USA) and data were analyzed with WinMDI 2.8 software.

\section{Hepatocyte function tests}

Hepatocyte function tests were performed at confluence in 6-well plates. After washing the cells twice with phosphate buffered saline (PBS, NBPI International) culture medium was replaced by $2.5 \mathrm{~mL}$ of test medium (William's E medium with 4\% HI-FBS, 2 mM L-glutamine, 1 $\mu \mathrm{M}$ dexamethason, $20 \mathrm{mU} / \mathrm{mL}$ insulin (Novo Nordisk), 2 $\mathrm{mM}$ ornithine (Sigma-Aldrich), $100 \mathrm{U} / \mathrm{mL}$ penicillin, 100 $\mu \mathrm{g} / \mathrm{mL}$ streptomycin, $0.5 \mathrm{mM} \mathrm{NH} 4 \mathrm{Cl}, 2.75 \mathrm{mM}$ D-galactose (Sigma), $90 \mu \mathrm{M}$ lidocaine $\mathrm{HCl}$ (Sigma-Aldrich). Medium samples were taken after 0 and 72 hours of incubation. The cells were then washed twice with PBS and stored at $-20^{\circ} \mathrm{C}$ for protein determination.

\section{Biochemical assays}

Urea concentrations were determined using the blood urea nitrogen test (Sigma Chemical Co). Albumin concentrations were determined via enzyme linked immunosorbent assays using cross-absorbed goat-anti-human albumin antibodies (Bethyl). Lidocaine concentrations were measured by fluorescence polarization immunoassay using a TDxFLx analyzer (Abbot Laboratories). Galactose concentrations were determined by the absorbance of nicotinamide-adenine dinucleotide (NADH) at $340 \mathrm{~nm}$ after enzymatic reaction with galactose dehydrogenase (Roche). Total protein/well was quantified by spectrometry using Coomassie blue (Bio-Rad). Production rates were established by calculating the changes in concentration during time and corrected for protein content.

\section{RT-PCR}

RNA was isolated from the cell lines by using TRIzol (Boehringer Mannheim). As a reference, human liver samples were included in the analyses. First strand cDNA was generated from $500 \mathrm{ng}$ of total RNA using $20 \mathrm{pmol}$ of genespecific RT primers specific for the mRNA of Albumin, $\alpha$ 1-Antitrypsin (AAT), Transferrin, Hepatocyte Nuclear Factor $4 \alpha(\mathrm{HNF} 4 \alpha)$, Alpha-fetoprotein (AFP), $\pi$ class Glutathione $S$ transferase (GST $\pi$ ) and hTERT in combination with 5 pmol of RT primer for $18 \mathrm{~S}$ ribosomal RNA and 134 units Superscript III (Invitrogen). Real-time reverse transcription PCR (RT-PCR) using SYBR green I (Roche) was performed as described previously [18]. The sequences of the RT and PCR primers and PCR conditions are given in Table 1.

Starting levels of mRNA, except for hTERT, were calculated by analyzing linear regression on the Log (fluorescence) per cycle number data using LinRegPCR software [19].
Starting levels of hTERT mRNA were calculated by standard curve analysis, using serial dilutions of hTERT containing plasmid ranging from $10^{2}$ to $10^{9}$ copies/reaction and LightCycler software (Roche). The mRNA starting levels of Albumin, AAT, Transferrin, AFP, GST $\pi$, and hTERT were normalised for the starting levels of $18 \mathrm{~S}$ ribosomal RNA. Normalised mRNA levels, except for hTERT mRNA levels, are expressed as a percentage of the mean mRNA starting levels of the two liver samples normalised for $18 \mathrm{~S}$ ribosomal RNA starting levels.

\section{Immunocytochemistry}

For the detection of glutamine synthetase (GS), cBAL111 cells were cultured on 8-wells culture-slides (BD Falcon) for two days. Then the cells were washed twice with PBS and fixed by a 10-minutes incubation with ice-cold methanol-aceton-water mixture (2:2:1). Cells were incubated with $70 \%$ ethanol for 5 minutes, washed with PBS and subsequently incubated overnight with monoclonal GS antibody (Transduction Laboratories, Lexington, KY, G45020) diluted 1:1000. Antibody binding was visualized with the indirect unlabelled antibody peroxidase anti-peroxidase (PAP) method [20].

For the detection of albumin, cytokeratin (CK) 18 and CK19, cBAL111 cells were seeded on Immunoslides (ICN, Aurora, Ohio, USA) and cultured for two and 15 days. Cells were washed once in PBS with $0.1 \%$ Tween-20 and fixated in $4 \%$ paraformaldehyde in PBS for 15 minutes at room temperature. Cells were washed as before and incubated with a blocking buffer (3\% BSA, 0,2\% Fish gelatin (Sigma), 2\%FCS) for one hour at room temperature. After a further washing step, the cells were incubated with the primary antibody for one hour at room temperature. As primary antibodies we used anti-albumin antibody (Sigma), mouse-anti-human CK18 (sc-6259, Santa Cruz) and mouse-anti-human CK19 (Santa Cruz) for detection of albumin, CK18 and CK19, respectively. Cells were washed again as before and incubated with $28 \mu \mathrm{g} / \mathrm{mL}$ Cy 2 conjugated goat-anti-mouse IgG and $1 \mu \mathrm{g} / \mathrm{mL}$ tetramethylrhodamine isothiocyanate (TRITC) conjugated phalloidin for 1 hour in a humidified chamber at room temperature. Forty minutes before the end of this incubation period, $20 \mathrm{ng} / \mathrm{mL}$ Diamidinophenylindoldiacetate (DAPI) was added. Cells were washed again as before and embedded in Polymount (Polyscience, Washington, USA) and covered with a coverslip. Slides were analysed using an Axiovert 200 fluorescence microscope.

\section{Soft Agar assay}

Cells were added to $0.35 \%$ low-melting-temperature agarose (Seaplaque) containing DMEM culture medium as described above and transferred at a density of 5000 cells/ well to 6 -well plates previously lined with $0.5 \%$ agar 
Table I: Primers and conditions used in RT-PCR analysis

\begin{tabular}{|c|c|c|c|c|c|c|}
\hline \multirow[t]{2}{*}{ Gene } & \multirow{2}{*}{$\begin{array}{l}\text { Sense primer } 5^{\prime} \rightarrow \\
3^{\prime}\end{array}$} & \multirow{2}{*}{$\begin{array}{l}\text { Antisense primer } \\
5^{\prime} \rightarrow 3^{\prime}\end{array}$} & \multirow[t]{2}{*}{ Application } & \multirow[t]{2}{*}{ Size amplicon (bp) } & \multicolumn{2}{|c|}{ PCR conditions } \\
\hline & & & & & Dilution template & $\begin{array}{c}\text { Annealing temp. } \\
\left({ }^{\circ} \mathrm{C}\right)\end{array}$ \\
\hline I8S rRNA & NA & $\begin{array}{l}\text { CGAACCTCCGAC } \\
\text { TTTCGTTT }\end{array}$ & RT & & NA & \\
\hline AAT & NA & $\begin{array}{l}\text { GGGGGATAGACA } \\
\text { TGGGTATGG }\end{array}$ & RT & & NA & \\
\hline AFP & NA & $\begin{array}{l}\text { CGTTTTGTCTTCT } \\
\text { CTTCCCC }\end{array}$ & RT & & NA & \\
\hline Albumin & NA & $\begin{array}{l}\text { ACTTCCAGAGCT } \\
\text { GAAAAGCATGGT } \\
\text { C }\end{array}$ & RT & & NA & \\
\hline GST $\pi$ & NA & $\begin{array}{l}\text { AGCAGGTCCAGC } \\
\text { AGGTTG }\end{array}$ & RT & & NA & \\
\hline HNF4 $\alpha$ & NA & $\begin{array}{l}\text { CACTCCAACCCC } \\
\text { GCСССТC }\end{array}$ & RT & & NA & \\
\hline hTERT & NA & $\begin{array}{l}\text { CAGAGCAGCGTG } \\
\text { GAGAGGATG }\end{array}$ & RT & & NA & \\
\hline Transferrin & NA & $\begin{array}{l}\text { CCAGACCACACT } \\
\text { TGCCCGCTATG }\end{array}$ & RT & & NA & \\
\hline I $8 S$ rRNA & $\begin{array}{l}\text { TTCGGAACTGAG } \\
\text { GCCATGAT }\end{array}$ & $\begin{array}{l}\text { CGAACCTCCGAC } \\
\text { TTTCGTTT }\end{array}$ & PCR & 151 & $1000 x$ & $68 \rightarrow 63$ \\
\hline AAT & $\begin{array}{l}\text { ACAGAAGGTCTG } \\
\text { CCAGCTTC }\end{array}$ & $\begin{array}{l}\text { GATGGTCAGCAC } \\
\text { AGCCTTAT }\end{array}$ & PCR & 181 & - & $68 \rightarrow 63$ \\
\hline AFP & $\begin{array}{l}\text { TKCCAACAGGAG } \\
\text { GCYATGC }\end{array}$ & $\begin{array}{l}\text { CCCAAAGCAKCA } \\
\text { CGAGTTTT }\end{array}$ & PCR & 306 & - & $62 \rightarrow 55$ \\
\hline Albumin & $\begin{array}{l}\text { TGAGCAGCTTGG } \\
\text { AGAGTACA }\end{array}$ & $\begin{array}{l}\text { GTTCAGGACCAC } \\
\text { GGATAGAT }\end{array}$ & PCR & 189 & - & $68 \rightarrow 63$ \\
\hline GST $\pi$ & $\begin{array}{l}\text { GCCAGAGCTGGA } \\
\text { AGGAGG }\end{array}$ & $\begin{array}{l}\text { TTCTGGGACAGC } \\
\text { AGGGTC }\end{array}$ & PCR & 333 & $10 x$ & $70 \rightarrow 63$ \\
\hline HNF4 $\alpha$ & $\begin{array}{l}\text { CCGGGTGTCCAT } \\
\text { ACGCATCCT }\end{array}$ & $\begin{array}{l}\text { CAGGTTGTCAATC } \\
\text { TTGGCC }\end{array}$ & PCR & 321 & - & $68 \rightarrow 63$ \\
\hline hTERT & $\begin{array}{l}\text { CGTACTGCGTGC } \\
\text { GTCGGTAT }\end{array}$ & $\begin{array}{l}\text { GGTGGCACATGA } \\
\text { AGCGTAGG }\end{array}$ & PCR & 233 & - & $68 \rightarrow 63$ \\
\hline Transferrin & $\begin{array}{l}\text { GAAGGACCTGCT } \\
\text { GTTTAAGG }\end{array}$ & $\begin{array}{l}\text { CTCCATCCAAGCT } \\
\text { CATGGC }\end{array}$ & PCR & 310 & - & $68 \rightarrow 63$ \\
\hline
\end{tabular}

Sequences of the primers used in Reverse Transcriptase (RT) reaction or during real-time PCR reaction (PCR) and the conditions used in the realtime PCR reactions. NA = not applicable. 
DMEM culture medium. After 15 days, the colonies were stained with $0.005 \%$ Crystal violet and counted.

\section{Transplantation}

The cBAL111 cells overexpressing GFP were transplanted into four 6 week old Rag2-/- $\gamma \mathrm{c}-/$ - mice [21]. The mice were anesthetized with an intraperitoneal injection of FFM mixture (2.5 mg Fluanisone/0.105 mg Fentanyl citrate/ $0.625 \mathrm{mg}$ Midazolam $\mathrm{HCl} / \mathrm{kg}$ in $\mathrm{H}_{2} \mathrm{O}, 7 \mathrm{~mL} / \mathrm{kg}$ ). One million GFP-marked cBAL111 cells suspended in $100 \mu \mathrm{L}$ HBSS were injected into the inferior tip of the spleen as described [22]. At both nine and 34 days after transplantation, two mice were sacrificed. The livers and spleens were harvested after in vivo fixation. For in vivo fixation, mice were anesthetized as described above and $25 \mathrm{~mL}$ PBS was flushed trough the circulation, followed by $25 \mathrm{~mL} 2 \%$ paraformaldehyde (PFA) in PBS. Subsequently, liver and spleen were harvested and cut into pieces of approximately $0.2 \mathrm{~cm}^{3}$. The tissue pieces were incubated in $4 \%$ PFA in PBS for four hours, followed by an overnight incubation in 30\% sucrose solution. Tissues were snap frozen in liquid nitrogen and stored at $-80^{\circ} \mathrm{C}$.

\section{Immunohistochemistry}

Cryosections were $6 \mu \mathrm{m}$ thick and were mounted on polyL-lysine coated slides. Sections were incubated in Teng-T (10 mM Tris, $5 \mathrm{mM}$ EDTA, $0.15 \mathrm{M} \mathrm{NaCl}, 0.25 \%$ gelatin and $0.05 \%$ Tween-20, pH 8.0) for 30 minutes before incubation with primary antibodies. Human mitochondria were visualized with a mouse-anti-human mitochondria antibody (Chemicon International) in a 150-fold dilution; vimentin was visualized with a mouse-anti-vimentin antibody, clone 9 (Boehringer Mannheim) in a 1000-fold dilution; carbamoylphosphate synthetase (CPS) was visualized with rabbit-anti-CPS antibody in a 1500-fold dilution and glutamine synthetase (GS) was visualized with monoclonal GS antibody (Transduction Laboratories) in a 500-fold dilution, human albumin was visualized with goat-anti-human albumin antibody in a 1:200 fold dilution. As a secondary antibody Alexa594 conjugated goatanti-mouse IgG (Molecular Probes) was used in a 1000fold dilution for the detection of vimentin and human mitochondria and in a 250 -fold dilution for detection of GS. CPS antibodies were detected with Alexa594 conjugated goat-anti-rabbit IgG (Molecular Probes) in a 250fold dilution. Goat-anti-human albumin immunoglobulins were detected using rabbit-anti-goat IgG conjugated with Alexa 594 (Molecular Probes). Slides were mounted in Vectashield containing $1 \mu \mathrm{g} / \mathrm{mL}$ 4,6-diaminidino-2phenylindole (DAPI) to counterstain DNA.

\section{FISH analysis}

Fluorescent in situ hybridization (FISH) analysis was performed on $6 \mu \mathrm{m}$ sections of paraffin embedded liver tissue as described before [23]. Briefly, sections were treated to remove paraffin and the sections were denatured in $70 \%$ formamide for 2.5 minutes. $150 \mathrm{ng}$ Biotin 11-dUTP labeled human genomic DNA, $200 \mathrm{ng}$ digoxigenin 11dUTP labeled murine genomic DNA and $5 \mu \mathrm{g}$ salmon sperm DNA were denatured together and hybridized overnight at $37^{\circ} \mathrm{C}$ with the sections. After washing the slides, human DNA was visualized with FITC anti-avidin followed by biotinylated anti-avidin antibodies (Vector laboratories), whilst mouse genomic DNA was visualized with sheep rhodamine anti-digoxigenin followed by Texas red anti-sheep antibodies (Vector laboratories). Slides were mounted in Vectashield (Vector laboratories) containing $1 \mu \mathrm{g} / \mathrm{mL}$ DAPI to counterstain DNA.

\section{Statistical analysis}

Student's t tests were used to determine statistical differences. Significance was reached if $P<0.05$. SPSS 12.0.1 (SPSS Inc., Chicago, IL, USA) was used for statistical analysis. Average values ( \pm standard error) are reported.

\section{Results}

Human TERT introduction in HFLCs and clonal derivatives The maximum number of PDs between the HFLC preparations and clonal derivatives were different. Expression of hTERT was detected in some of the clonal derivatives analysed, however, all HFLCs and clonal derivatives eventually entered a state of terminal growth arrest (Table 2).

After lentiviral introduction of the hTERT gene, the presence of the hTERT CDNA was confirmed in HFLCs and clonal derivatives by PCR on genomic DNA (results not shown). However, the HFLC cultures did not overcome the terminal growth arrest after the introduction of the hTERT gene; only one of the HFLC cultures' lifespan was extended by $30 \%$. In addition, only one of the clonal derivatives was able to overcome the terminal growth arrest after the introduction of hTERT. This clone, cBAL08, previously showed the longest life span of 61 PDs and a relatively high endogenous hTERT expression (Table 2). Because the transduced cell line was capable of more than 120 PDs, which is twice the life span of the parental cell line cBAL08, and still did not show any sign of growth arrest, we considered this cell line to be immortalized and named it cBAL111. The hTERT mRNA levels of cBAL111 were $1 \times 10^{5}$-fold higher as compared to its parental cell line cBAL08 (Table 2).

\section{Characterisation of $C B A L I$ I I in vitro}

The organisation of the cBAL111 cell layer changed during culturing; the cells displayed a cubic shape at day 15 (Fig. 1C and 1D) instead of the more spindle shape at day 2 (Fig. $1 \mathrm{~A}$ and $1 \mathrm{~B}$ ). The cBAL111 cultures were 100\% positive for the hepatocyte markers GS, CK 18 and albumin as well as the cholangiocyte marker CK 19 at day 2 and day 15 after seeding (GS and albumin are shown at day 2 and 
Table 2: The life span and the hTERT mRNA levels of three different HFLC isolates, clonal derivatives and cBALI I I

\begin{tabular}{lll}
\hline Cell source & Maximal PDs & hTERT mRNA copies/ 8S rRNA copies \\
\hline HFLCs, 16 weeks & $57.6 \pm 10.2$ & Undetectable $(n=4)$ \\
\hline cBAL08 & 61 & $2.7 * 10^{4}(n=1)$ \\
\hline cBAL09 & 30 & Not determined \\
\hline CBAL20 & 38 & Undetectable $(n=1)$ \\
\hline cBAL2I & 31 & Undetectable $(n=1)$ \\
\hline CBAL29 & 42 & $2.4 * 10^{5} \pm 1.9 * 10^{5}(n=3)$ \\
\hline CBALIII & Immortal & $2.6 * 10^{9} \pm 3.2 * 10^{8}(n=4)$ \\
\hline
\end{tabular}

Life span is indicated as the maximum number of population doublings (PDs).

CK18 and CK19 are shown at day 15 in Fig. 1). The CK18 staining was predominantly around the nucleus reaching into the cytoplasm, which is similar to the CK18 staining of primary human hepatocytes that are dedifferentiating in vitro [24]. These data suggest that under these conditions the cBAL111 cells resemble cells with progenitor characteristics rather than fully differentiated hepatocytes.

The 15 day-cultured cBAL111 cells and, for comparison, hepatoblastoma derived HepG2 cells were characterized for three progenitor cell markers by flow cytometry, i.e. CD146, a marker for various cells including mesenchymal progenitor cells and hepatocytes during liver regeneration $[25,26]$, CD326 (EpCAM), an epithelial marker upregulated in gastrointestinal carcinomas [27] and CD133, a marker for progenitor cells of various origins, like endothelial cells, haematopoietic cells and neural cells [28]. The cBAL111 cells were positive for CD146, but negative for CD326 (EpCAM) (Fig. 2A and 2B) and CD133 (data not shown). HepG2 cells were also negative for CD133 (data not shown), but, in contrast to the cBAL111 cells, positive for CD326 and negative for CD146 (Fig. 2C and 2D).

Because the immunostainings suggested a transition in the organisation of the cell layer of cBAL111 cells, we tested their in vitro functionality at 2 days of culture, when the cells displayed a spindle like morphology and the culture was not confluent and at day 15, when cells were more cubic and confluence was reached. There was a trend of increased expression of markers for mature hepatocytes (production of albumin and urea, galactose elimination and transcript levels of transferrin, AAT and HNF $\alpha$ ) with culture time and decreased expression of markers for immature hepatocytes (GST $\pi$ and AFP) (Table 3). The in vitro functionality of cBAL08 after reaching confluence was comparable with that of cBAL111, particularly at day 15; no significant difference was detected between cBAL08 and cBAL111 at day 15 for urea and albumin production and the mRNA levels of Albumin, AAT, Transferrin, GST $\pi$ and AFP differed less than 2.5-fold (Table 3). So, the immortalization of cBAL08 maintained the investigated hepatic functions. Further extension of the culture period did not clearly increase hepatic functionality (results not shown).

To investigate the putative tumorigenicity of CBAL111, the cells were seeded in soft agar. The cBAL111 cells were not able to form colonies in soft agar, where HepG2 as positive control, formed $61 \pm 21$ colonies from 5000 cells. The inability of cBAL111 cells to grow in an anchorage independent way, is an indication that CBAL111 cells are not tumorigenic.

\section{Comparison of CBALI I I with other hepatic cell lines and mature hepatocytes}

The novel in vitro immortalized fetal hepatocyte cell line cBAL111 was subsequently compared with HepG2 cells, the conditionally immortalized hepatocyte cell line NKNT-3 and primary (mature) human hepatocytes two days after seeding. The primary human hepatocytes did not exhibit any decline in the tested functions within two days (results not shown). HepG2, cBAL111 at day 15 and NKNT-3 cells, both un-reverted and reverted for immortalization, synthesized urea, at a level 11-32 fold lower than mature hepatocytes (Table 3). The HepG2 cells and to a lesser extent the cBAL111 cells produced albumin in contrast to NKNT-3 cells. The galactose elimination of the cBAL111 cells at day 15 reached to $19 \%$ of the levels of the mature hepatocytes. The cBAL111 cells, like fetal hepato- 

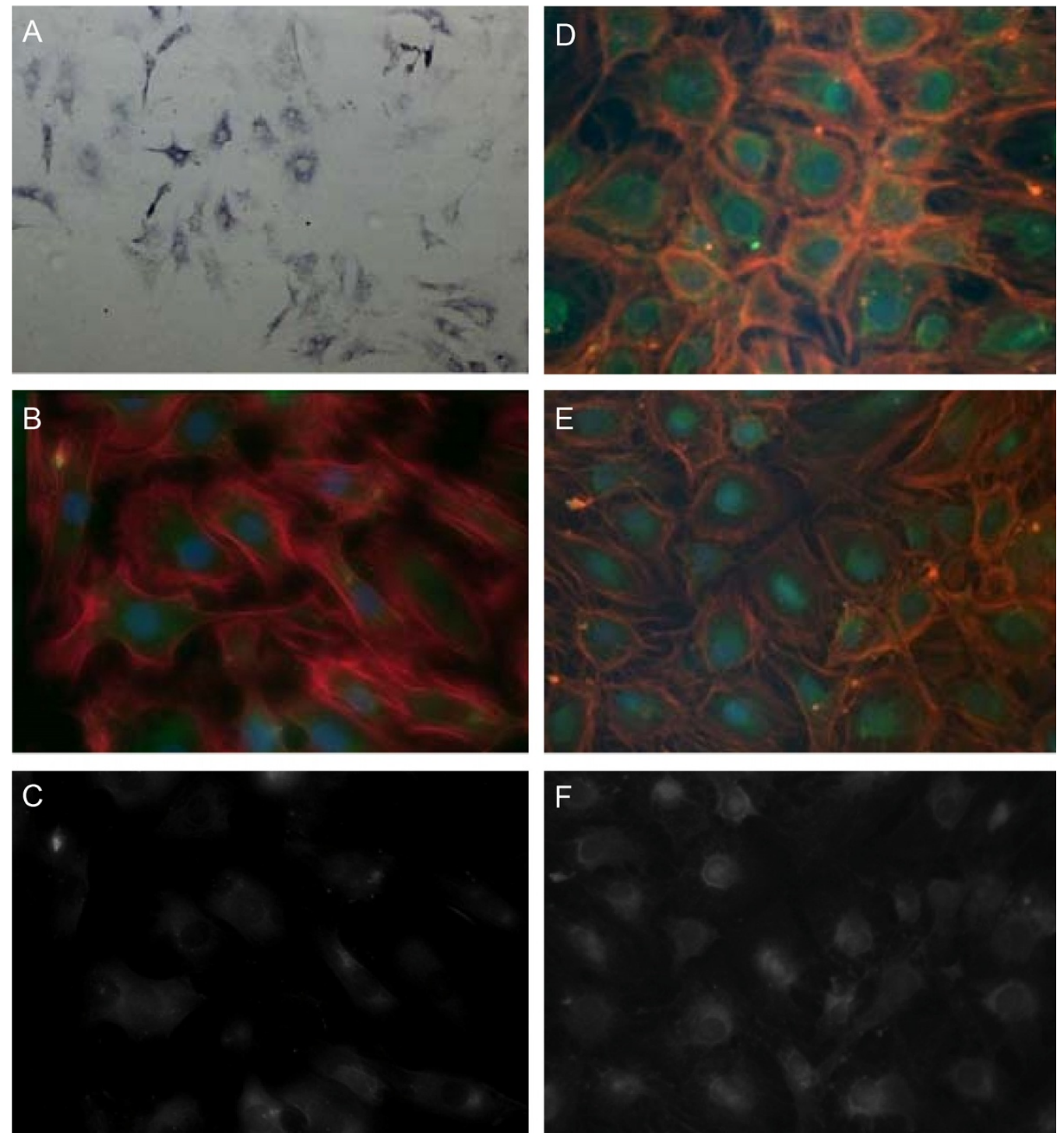

Figure I

Immunostainings of cBALI I I cells in vitro. The cells were stained using antibodies against GS (A) (blue, 40× magnification, 2 days in culture), albumin (B, C) (green, 400x magnification, 2 days in culture) and CKI 9 (D) or CKI8 (E, F) (both green, $400 \times$ magnification, I 5 days in culture). In the CKI8, CKI9 and albumin staining, cells were further visualized by phalloidin, binding to actin (red), and DAPI, binding to the nuclei (blue) $(B, D, E)$. Corresponding single stains of albumin and $C K I 8$ are shown in $C$ and $F$.

cytes, did not eliminate lidocaine, a marker for cytochrome P450 1A2 and 3A4 activity, whereas the mature hepatocytes eliminated $9.8 \pm 9.3 \mathrm{nmol} / \mathrm{h} / \mathrm{mg}$ protein.

In cBAL111 and NKNT-3 cells, the mRNA levels of albumin, AAT and transferrin, (markers of hepatocyte differentiation) were less than $1 \%$ of the corresponding levels in human liver. However, the transcript levels of HNF4 $\alpha$, a master regulator of liver development, increased up to
$17 \%$ of the human liver levels in the cBAL111 cells at day 15. HepG2 cells showed mRNA levels for albumin, AAT and transferrin that were comparable to human liver. As markers associated with immature hepatocytes, AFP mRNA levels of cBAL111 and NKNT-3 cells were comparable to the in vivo level, while the GST $\pi$ mRNA levels were 10-44 times higher. In HepG2 cells, mRNA levels for AFP were 1000-fold higher than the in vivo levels and GST $\pi$ levels were undetectable. In summary cBAL111 at day 

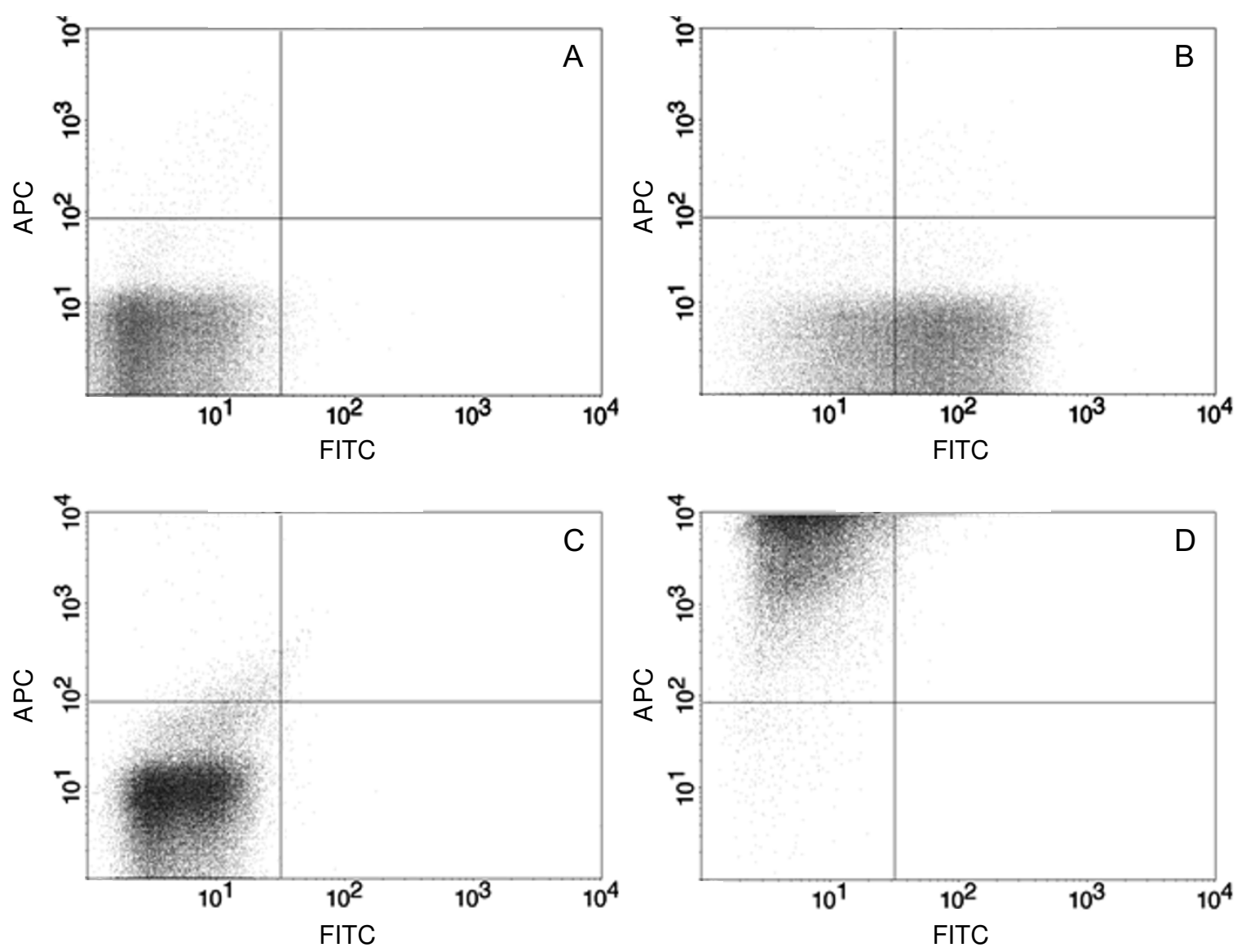

Figure 2

Dotplots of flow cytometry analysis of CDI46 and CD326 expression of cBALI I I cells (A, B) and HepG2 cells (C, D). (A, C) Negative isotype controls, (B, D) cells labeled with anti-CD I46-FITC and anti-CD326-APC.

15 was positive for all tested hepatocyte parameters, whereas HepG2 and NKNT-3 cells both lacked one function.

\section{cBAL I I cells differentiate into functional hepatocytes in murine liver}

To determine whether cBAL111 cells have the potential for hepatic differentiation, the cells were marked with GFP by lentiviral transduction and transplanted in the spleen of 4 immunodeficient mice. Nine and 34 days after transplantation, GFP expressing cells were detected in the murine spleen (results not shown) and liver (Fig. 3A and $3 \mathrm{~B})$. The presence of GFP positive cells in the murine livers was relatively low $(\sim 1 \%)$, since no liver repopulation model was applied, and remained stable between nine and 34 days. The cells appeared as single cells and no cell clusters were detected, which again suggested a lack of tumorigenicity.

The majority of these cells exhibited an elongated morphology, however a small number of cells $(\sim 1 \%)$ had the morphological characteristics of hepatocytes, given their cuboid appearance. No differences were observed between the livers harvested at nine and 34 days after transplantation. The GFP positive cells were confirmed to be from human origin by immunohistochemistry using a human specific antibody binding to mitochondria (Fig. 3C and 3D). Immunohistochemistry using an antibody against vimentin, a marker for dedifferentiated and mesenchymal cells [29], indicated a high expression in cBAL111 in vitro (data not shown) and in all the elongated cBAL111 cells found in the mouse liver, whereas the cBAL111 cells with cuboid appearance did not or hardly expressed vimentin (Fig. 3E). Furthermore these GFP positive hepatocyte-looking cells with cuboid morphology were indistinguishable from the surrounding mice hepatocytes with regards to CPS expression, which is expressed periportally [30] (Fig. 3F). In contrast, elongated cBAL111 cells did not express CPS. GS expression, which is present in vitro (Fig. 1), was absent in the transplanted cells in the periportal areas (Fig. 3G). No GFP positive cells were detected in pericentral areas, the site of GS expression in 
Table 3: Hepatic functions of different hepatic cell lines and primary mature human hepatocytes (Mat Hep)

\begin{tabular}{|c|c|c|c|c|c|c|c|c|c|}
\hline \multirow[b]{2}{*}{ Cell } & \multicolumn{3}{|c|}{ Hepatic function $(n=9)$} & \multicolumn{4}{|c|}{$\begin{array}{l}\text { mRNA levels }(n=3) \\
\text { Mature hepatic marker }\end{array}$} & \multicolumn{2}{|c|}{$\begin{array}{c}\text { mRNA levels }(n=3) \\
\text { Immature hepatic } \\
\text { marker }\end{array}$} \\
\hline & $\begin{array}{l}\text { Albumin } \\
\text { production } \\
\text { (ng/h/mg } \\
\text { protein) }\end{array}$ & $\begin{array}{l}\text { Urea } \\
\text { production } \\
\text { (nmol/h/ } \\
\text { mg } \\
\text { protein) }\end{array}$ & $\begin{array}{c}\text { Galactose } \\
\text { elimination } \\
(\mu \mathrm{mol} / \mathrm{h} / \\
\text { mg } \\
\text { protein) }\end{array}$ & Albumin & Transferrin & AAT & HNF4 & $\mathbf{G S T} \pi$ & AFP \\
\hline Mat Hep & $37.7 \pm 7.7$ & $91.5 \pm 33.7$ & $0.58 \pm 0.44$ & 130 & 245 & $12 \mid$ & $14 \mid$ & 535 & ND \\
\hline cBAL08 & $0.3 \pm 0.4$ & $4.0 \pm 1.6$ & ND & $0.02 \pm 0.01$ & $0.20 \pm 0.14$ & $0.32 \pm 0.14$ & ND & $1000 \pm 565$ & $78 \pm 61$ \\
\hline $\begin{array}{l}\text { CBALIIII } \\
\text { day } 2\end{array}$ & $\begin{array}{c}\text { Undetectabl } \\
\mathrm{e}\end{array}$ & $\begin{array}{l}\text { Undetectabl } \\
\mathrm{e}\end{array}$ & $0.04 \pm 0.02$ & $0.02 \pm 0.01$ & $0.11 \pm 0.05$ & $0.02 \pm 0.01$ & $1.3 \pm 1.3$ & $1944 \pm 1010$ & $122 \pm 11$ \\
\hline $\begin{array}{l}\text { CBALIIII } \\
\text { day } 15\end{array}$ & $0.7 \pm 0.8$ & $8.0 \pm 6.6$ & $0.11 \pm 0.03 *$ & $0.02 \pm 0.01$ & $0.20 \pm 0.06$ & $0.05 \pm 0.01$ & $17.2 \pm 5.6^{*}$ & $|374 \pm 67|$ & $114 \pm 10$ \\
\hline HepG2 & $2.8 \pm 0.3$ & $4.7 \pm 0.2$ & ND & $63 \pm 6$ & $896 \pm 110$ & $199 \pm 56$ & ND & $\begin{array}{l}\text { Undetectabl } \\
\mathrm{e}\end{array}$ & $\begin{array}{c}93353 \pm \\
13228\end{array}$ \\
\hline $\begin{array}{l}\text { NKNT-3 } \\
\text { reverted }\end{array}$ & $\begin{array}{l}\text { Undetectabl } \\
\mathrm{e}\end{array}$ & $4.9 \pm 9.4$ & ND & $0.24 \pm 0.22$ & $0.16 \pm 0.12$ & $0.92 \pm 1.52$ & ND & $952 \pm 1164$ & $117 \pm 166$ \\
\hline $\begin{array}{l}\text { NKNT-3 } \\
\text { unreverted }\end{array}$ & $\begin{array}{c}\text { Undetectabl } \\
\mathrm{e}\end{array}$ & $2.9 \pm 5.2$ & ND & $0.42 \pm 0.66$ & $0.20 \pm 0.13$ & $0.26 \pm 0.34$ & ND & $4427 \pm 5366$ & $65 \pm 79$ \\
\hline
\end{tabular}

MessengerRNA levels are expressed as a percentage of the mean mRNA levels of the two liver samples. ND $=$ not determined

* cBALIII day 2 versus CBALIII day I5; $\mathrm{P}<0.05$

normal liver. A possible explanation for this is that the cells may have entered the liver via the portal vein and engrafted before reaching the pericentral area. Finally, the cuboid GFP positive cells stained positive for human albumin (Fig. 3H-J), whereas the elongated GFP positive cells were negative (not shown).

We then tested whether the GFP positive hepatocytes were the result of fusion between human cBAL111 cells and murine hepatocytes [31], by using FISH analysis. The results showed that nuclei reacting to the human probe (Fig. 4A and 4D) were negative for the murine probe (Fig. $4 \mathrm{C}$ and $4 \mathrm{~F}$ ). From the shape of the nuclei and the localization of cells, we concluded that these were cBAL111 derived hepatocytes.

\section{Discussion}

In this report we present a novel, clonal, immortalized human fetal liver cell line, cBAL111, that displays hepatocyte-specific functions. In vitro, the cBAL111 cell line produced albumin and urea and expressed hepatocytespecific genes. However, the levels of the hepatic functions showed considerable variation compared with primary mature hepatocytes. Moreover, the cBAL111 cells expressed immature markers CD146, cytokeratin 19 and glutathione $S$ transferase $\pi$, but did not show any evidence of growth in soft agar. In vivo, when cBAL111 was transplanted in immunodeficient mice, the cell line showed the potential to fully differentiate into hepatocytes and adapt the zonal expression pattern of CPS.

Human fetal liver cells have been immortalised by telomerase activation before [12], but this is the first report in which this immortalisation strategy was combined with a cloning procedure. In contrast to Wege et al. we could not immortalise unselected HFLC preparations [12], although we were able to extend the life span of the cells by about $30 \%$. In our study we selected cells with cuboid morphology from the initial cell preparation and of these selected cells only the cell line with the highest proliferation capacity, cBAL08, became immortal by overexpression of hTERT. The reduced ability of immortalization in the present study may be the result of differences in transduction levels observed in the two studies. Wege et al used a constitutively active Moloney murine leukemia promoter to drive hTERT expression [12]; we used a tetracycline inducible expression system, stimulated with $1 \mu \mathrm{M}$ doxycyclin, to drive hTERT expression. Because Moloney 

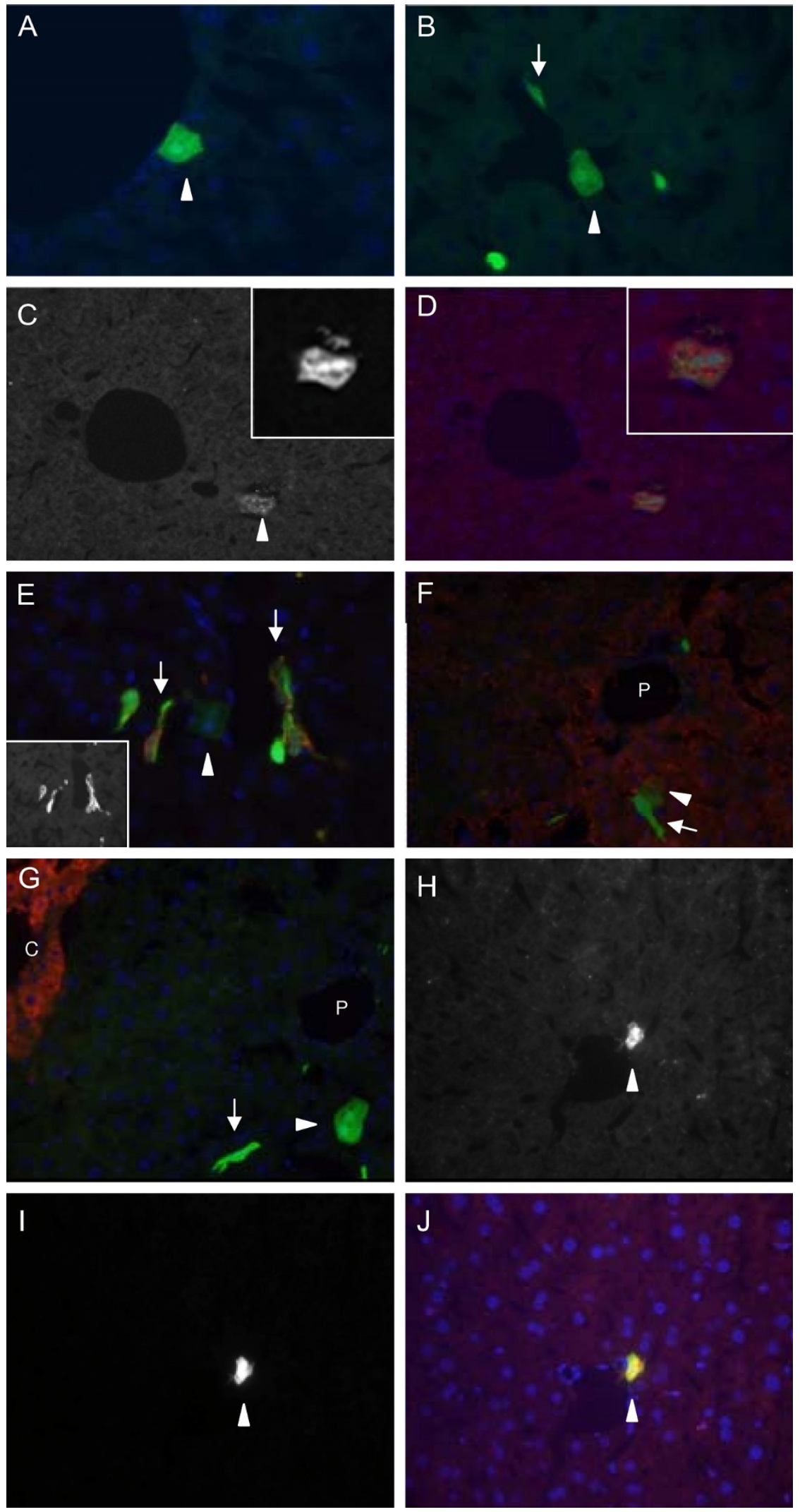

Figure 3 (see legend on next page) 
Figure 3 (see previous page)

Immunofluorescence of mouse livers (40x magnification), harvested 9 days after transplantation of GFP marked cBALI I I cells (green). Nuclei were visualized by DAPI staining (blue) (A-F, I). The majority of cells exhibited an elongated morphology (arrows); a small number of cells adapted hepatocyte morphology (arrowheads, A and B). Human origin of the cells was confirmed using an antibody against human mitochondria (red) (C and D); Human mitochondria fluorescence (C), GFP fluorescence ( $C$ insert) and merge of human mitochondria and GFP fluorescence (D, insert shows higher magnification). With hepatic differentiation, the cells lost the expression of vimentin, a marker of undifferentiated mesenchymal cells (red; insert shows single stain) (E). Hepatocytes originating from CBALI I I are undistinguishable from the surrounding murine hepatocytes in CPS expression (red) (F). No cells originating from CBALI I I were found in pericentral regions; cBALI I I in vivo did not express GS (G). Transplanted cBALI I I cells with hepatocyte morphology showed co-localization of GFP and human albumin (red) $(\mathrm{H}-\mathrm{J})$; albumin fluorescence $(\mathrm{H})$, GFP fluorescence $(\mathrm{I})$ and merge of albumin and GFP fluorescence $(\mathrm{J})$. P, portal vein; $C$, central vein.

murine leukaemia vectors are prone to transduce rapidly dividing cells, this might have resulted in the selection of cells prone to immortalization.

Our results are in line with the conclusion of Wege et al that telomerase-induced immortalization of HFLCs does not affect their differentiation potential [12]. After immortalisation, cBAL111 was capable of reaching urea and albumin production rates and the hepatocyte specific mRNA levels comparable to the levels of cBAL08. However, cBAL111 needs prolonged cultivation time to produce albumin and urea. In addition, galactose elimination increased after prolonged culturing. This may be related to the increased transcript levels of $H N F 4 \alpha$, a key regulator of hepatocyte development and function [32].

Furthermore, we found no indications that cBAL111 was malignantly transformed; cBAL111 was not able to form colonies in soft agar and no tumours were found in immunodeficient mice 34 days after transplantation. We conclude that telomerase reconstitution can immortalize fetal human hepatocytes without loss of function and without indications of malignant transformation.

To our knowledge this is the first time that a hTERTimmortalized human fetal liver cell line was evaluated for hepatic function in vitro. The clonal origin of the cell line is most important for preservation of the phenotype during long-term culturing. The stability in phenotype was previously shown for cBAL08 [14]. This is in contrast to cultures of hepatocyte isolates from mature or fetal origin, either immortalized or not.

In addition to the description of cBAL111, we compared its functionality with that of mature human hepatocytes kept under the same culture conditions. It is rather surprising that such comparison is rarely seen in similar studies describing hepatic cell lines. Mature hepatocytes are currently the only cells that meet the criteria for in vitro applications and therefore are the gold standard when evaluating alternative hepatic cell lines. The performance of our novel hepatocyte line cBAL111 was also compared with two well-known and widely used hepatic cell lines, NKNT-3 [4] and HepG2 [3]. Admittedly all three cell lines, performed considerably less well compared with primary mature human hepatocytes in all the liver parameters tested in this study. NKNT-3 cell did not produce detectable levels of albumin; HepG2 cells lacked detectable GST $\pi$ expression. In concordance with the low level of hepatic differentiation, relatively high mRNA levels of AFP and particularly GST $\pi$ were observed in cBAL111. Moreover the cBAL111 cells expressed CK19, a marker for cholangiocytes, and in addition CK18, a marker for hepatocytes, in a pattern characteristic of de-differentiated human hepatocytes. Finally, the cBAL111 cells expressed CD146, a marker of various cells, including mesenchymal progenitor cells [25], Therefore it can be concluded that cBAL111 cells are not fully differentiated in vitro into mature hepatocytes, but rather should be regarded as a progenitor liver cell line that has the full potential to differentiate into hepatocytes. These cells may derive from mesodermal cells, as also suggested for multipotent progenitor cells previously isolated from human fetal liver [33].

Interestingly, HepG2 and cBAL111 showed contrasting expression patterns of CD146 and CD326. Both membrane glycoproteins are expressed on progenitor cells. However, CD326 is heavily upregulated in premalignant hepatic tissues and hepatocellular carcinomas and a marker for tumor-initiating stem cells, in contrast to CD146 [34,27,35]. Expression of CD146 is low in mature hepatocytes, but is upregulated in the termination phase of liver regeneration and in primary hepatocytes in the presence of transforming growth factor (TGF)- $\beta 1$. These observations underline the non-transformed phenotype of cBAL111 cells in contrast to HepG2 cells.

The liver provides an optimal environment for hepatic differentiation of cBAL111. When cBAL111 cells were labelled with GFP and transplanted into the spleen of 

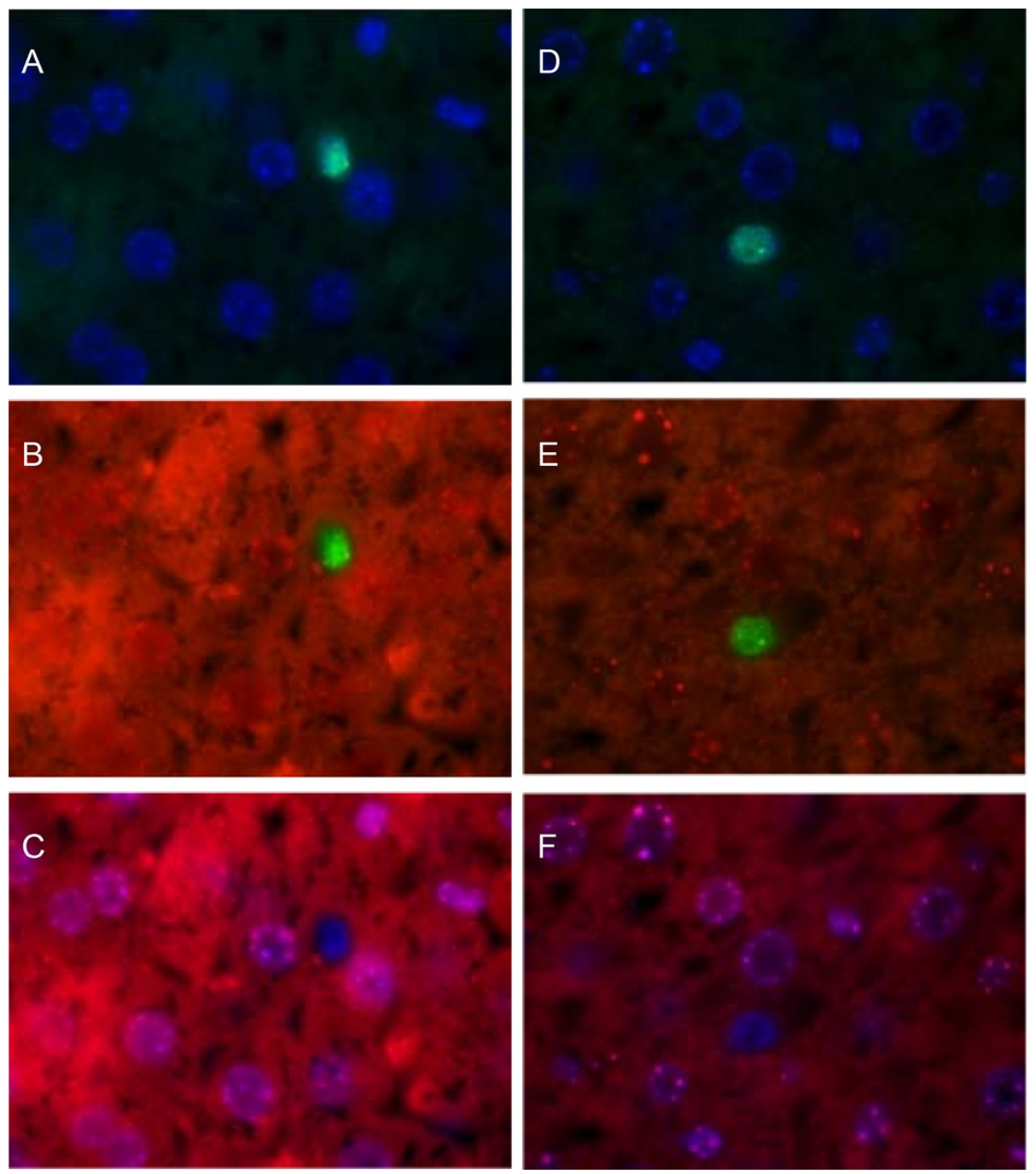

Figure 4

FISH analysis (40x magnification) of mouse livers after transplantation of GFP marked cBAL I I I cells. The probe hybridizing with human DNA was visualized using a FITC labeled antibody (A, B, D and E), showing green nuclei, the probe hybridizing with murine DNA was visualized using a Texas Red labeled antibody (red nuclear staining on top of cytoplasmic background autofluorescence, $B, C, E$ and $F$ ). All nuclei were counterstained using DAPI (blue A, C, D and F). Picture sets $A-C$ and D-F both show a human cell that is negative for the murine DNA.

immunodeficient mice the cells migrated to the liver. This was already shown with human fetal hepatocytes, both immortalized and freshly isolated $[36,12]$. However, in this study we showed that following engraftment a number of these cells went to become hepatocytes morphologically indistinguishable from murine hepatocytes. These cells had very low or no expression of vimentin, a marker for mesenchymal cells and for the undifferentiated cBAL111 cells. In addition, the cuboid cells expressed human albumin and adapted the zonal expression pattern of CPS and GS characteristic for the surrounding cells [30]. With FISH analysis, we excluded the possibility that these GFP positive hepatocytes were the result of fusion between GFP labelled cBAL111 cells and murine hepatocytes. Fusion between host liver cells and transplanted stem cells, specifically haematopoietic stem cells, has been widely reported to account for high rates of transdifferentiation $[37,31]$. Our experiments confirm that the cBAL111 line is able to differentiate into hepatocytes when the right differentiation stimuli are present.

However, the fact that a significant number of the transplanted cells did not adapt the hepatocyte morphology and expressed high levels of vimentin, but no human albumin, suggests that either not all cBAL111 cells were equally sensitive to differentiation stimuli, despite the 
clonal origin of the cells, or that not all cells were exposed to the same levels of differentiation stimuli due to microenvironmental variations. This requires further investigation.

Very recently we have tested the cBAL111 cells in the AMC-bioartificial liver (AMC-BAL), which is a bioreactor, more suitable for hepatocyte culturing than monolayer culturing $[38,39]$. We showed that the cBAL111 cells eliminated ammonia and galactose at a rate up to $49 \%$ and $90 \%$ of that of primary porcine hepatocytes in the AMC$\mathrm{BAL}$, respectively. Other functions, like albumin production and lidocaine elimination only reached $6 \%$ and $0.1 \%$ of the levels of primary porcine hepatocytes in the AMCBAL. This further underlines that the cBAL111 cells are indeed hepatocyte-like cells which probably need further stimulation of hepatic differentiation for in vitro applications.

\section{Conclusion}

The development of a cell line that combines both in vitro hepatic function and proliferation capacity is important for large-scale applications that depend on in vitro hepatic functionality. In this study we present evidence of a novel cell line cBAL111, which is a telomerase immortalized fetal human hepatocyte cell line capable to differentiate into mature hepatocytes in vivo. The potential of this novel cell line merits further investigation. The challenge is to define the best possible experimental conditions in vitro to mimic as closely as possible the differentiation stimuli present in vivo aiming to achieve a high degree of differentiation into mature hepatocytes in vitro.

\section{Authors' contributions}

TD carried out the immortalization and in vitro characterization of cBAL111 and drafted the manuscript. NPvT carried out the transplantations. AAC participated in the molecular biological studies. LtB participated in the molecular biological studiesRS carried out immunostainings. CP carried out the FISH analysis. JP coordinated the FISH analysis and helped to draft the manuscript. IMS coordinated the immunostainings. RAFMC conceived of the study, participated in the design of the study and coordination and helped to draft the manuscript. RPJOE participated in the design of the study and coordination and helped to draft the manuscript. JS participated in the design of the study and coordinated the transplantations. $\mathrm{RH}$ conceived of the study, participated in the design of the study, coordination and molecular biological studies and helped to draft the manuscript.

All authors read and approved the final manuscript.

\section{Acknowledgements}

We would like to thank Dr. Kees Weijer, Suzanne Ligthart, Arie Voordouw and Menno Ebeli, Amsterdam, for providing and processing fetal livers. We thank Gesine Pless for her contribution in the immunofluorescence staining experiments.

This research was supported by the Technology Foundation of NWO (project AGN.48I8), the Netherlands, and the European Union (project QLRT-200I-01889) for financial support.

\section{References}

I. Katsura N, Ikai I, Mitaka T, Shiotani T, Yamanokuchi S, Sugimoto S, Kanazawa A, Terajima H, Mochizuki Y, Yamaoka Y: Long-term culture of primary human hepatocytes with preservation of proliferative capacity and differentiated functions. J Surg Res 2002, I: II5-123.

2. Chen HL, Wu HL, Fon CC, Chen PJ, Lai MY, Chen DS: Long-term culture of hepatocytes from human adults. J Biomed Sci 1998, 6:435-440.

3. Nyberg SL, Remmel RP, Mann HJ, Peshwa MV, Hu WS, Cerra FB: Primary hepatocytes outperform Hep $G 2$ cells as the source of biotransformation functions in a bioartificial liver. Ann Surg. 1994, 220(I):59-67.

4. Kobayashi N, Fujiwara T, Westerman KA, Inoue Y, Sakaguchi M, Noguchi H, Miyazaki M, Cai J, Tanaka N, Fox IJ, Leboulch P: Prevention of acute liver failure in rats with reversibly immortalized human hepatocytes. Science 2000, 5456: |258-1262.

5. Hoekstra R, Deurholt T, Ten Bloemendaal L, Desille M, van Wijk ACWA, Clement B, Oude Elferink RP, van Gulik TM, Chamuleau RA: Assessment of in vitro, applicability of reversible immortalized NKNT-3 cells and clonal derivatives. Cell Transplant 2006, 5:423-433.

6. Li J, Li LJ, Cao HC, Sheng GP, Yu HY, Xu W, Sheng JF: Establishment of highly differentiated immortalized human hepatocyte line with simian virus $\mathbf{4 0}$ large tumor antigen for liver based cell therapy. ASAIO J 2005, 3:262-268.

7. Mills JB, Rose K, Sadagopan N, Sahi J, De Morais SM: Induction of drug metabolizing enzymes and MDRI using a novel hepatocyte cell line. J Pharmacol Exp Ther 2004, 39:303-309.

8. Pfeifer AM, Cole KE, Smoot DT, Weston A, Groopman JD, Shields PG, Vignaud JM, Juillerat M, Lipsky MM, Trump BF: Simian virus $\mathbf{4 0}$ large tumor antigen-immortalized normal human liver epithelial cells express hepatocyte characteristics and metabolize chemical carcinogens. Proc Natl Acad Sci USA 1993, II:5I23-5I 27.

9. Werner A, Duvar S, Muthing J, Buntemeyer H, Kahmann U, Lunsdorf $H$, Lehmann J: Cultivation and characterization of a new immortalized human hepatocyte cell line, HepZ, for use in an artificial liver support system. Ann N Y Acad Sci 1999 , 875:364-368.

10. Nguyen TH, Mai G, Villiger P, Oberholzer J, Salmon P, Morel P, Buhler $L$, Trono D: Treatment of acetaminophen-induced acute liver failure in the mouse with conditionally immortalized human hepatocytes. J Hepatol 2005, 6:103I-1037.

II. Colgin LM, Reddel RR: Telomere maintenance mechanisms and cellular immortalization. Curr Opin Genet Dev 1999, I:97-103.

12. Wege H, Le HT, Chui MS, Liu L, Wu J, Giri R, Malhi H, Sappal BS, Kumaran V, Gupta S, Zern MA: Telomerase reconstitution immortalizes human fetal hepatocytes without disrupting their differentiation potential. Gastroenterology 2003, 2:432-444.

13. Lazaro CA, Croager EJ, Mitchell C, Campbell JS, Yu C, Foraker J, Rhim JA, Yeoh GC, Fausto N: Establishment, characterization, and long-term maintenance of cultures of human fetal hepatocytes. Hepatology 2003, 5:1095-II06.

14. Deurholt T, Ten Bloemendaal L, Chhatta AA, van Wijk ACWA, Weijer K, Seppen J, Oude Elferink RPJ, Chamuleau RAFM, Hoekstra R: In vitro Functionality of Human Fetal Liver Cells and Clonal Derivatives under Proliferative Conditions. Cell Transplant 2006, 8-9:8II-822.

15. Seglen PO: Hepatocyte suspensions and cultures as tools in experimental carcinogenesis. J Toxicol Environ Health 1979, 2 3:55I-560.

16. Markusic D, Oude-Elferink R, Das AT, Berkhout B, Seppen J: Comparison of single regulated lentiviral vectors with rtTA expression driven by an autoregulatory loop or a constitutive promoter. Nucleic Acids Res 2005, 6:e63. 
17. Seppen J, Rijnberg M, Cooreman MP, Oude Elferink RP: Lentiviral vectors for efficient transduction of isolated primary quiescent hepatocytes. J Hepatol 2002, 4:459-465.

18. Hoekstra R, Deurholt T, Poyck PP, Ten Bloemendaal L, Chhatta AA: Increased Reproducibility of Quantitative Reverse Transcriptase-PCR. Analytical Biochemistry 2005, 340:376-379.

19. Ramakers C, Ruijter JM, Deprez RH, Moorman AF: Assumptionfree analysis of quantitative real-time polymerase chain reaction (PCR) data. Neurosci Lett 2003, I:62-66.

20. Sternberger LA, Hardy PH Jr, Cuculis JJ, Meyer HG: The unlabeled antibody enzyme method of immunohistochemistry: preparation and properties of soluble antigen-antibody complex (horseradish peroxidase-antihorseradish peroxidase) and its use in identification of spirochetes. J Histochem Cytochem 1970, 5:315-333.

21. Weijer K, Uittenbogaart CH, Voordouw A, Couwenberg F, Seppen J, Blom B, Vyth-Dreese FA, Spits $\mathrm{H}$ : Intrathymic and extrathymic development of human plasmacytoid dendritic cell precursors in vivo. Blood 2002, 8:2752-2759.

22. Ponder KP, Gupta S, Leland F, Darlington G, Finegold M, DeMayo J, Ledley FD, Chowdhury JR, Woo SL: Mouse hepatocytes migrate to liver parenchyma and function indefinitely after intrasplenic transplantation. Proc Natl Acad Sci USA I991, 4:1217-122I.

23. Newsome PN, Johannessen I, Boyle S, Dalakas E, McAulay KA, Samuel K, Rae F, Forrester L, Turner ML, Hayes PC, Harrison DJ, Bickmore WA, Plevris JN: Human cord blood-derived cells can differentiate into hepatocytes in the mouse liver with no evidence of cellular fusion. Gastroenterology 2003, 7:189|-1900.

24. Blaheta RA, Kronenberger B, Woitaschek D, Auth MK, Scholz M, Weber S, Schuldes H, Encke A, Markus BH: Dedifferentiation of human hepatocytes by extracellular matrix proteins in vitro: quantitative and qualitative investigation of cytokeratin 7, 8, 18, 19 and vimentin filaments. J Hepatol 1998, 4:677-690.

25. Shih IM: The role of CD I 46 (Mel-CAM) in biology and pathology. J Pathol 1999, I:4-II.

26. Tsuchiya S, Tsukamoto Y, Taira E, LaMarre J: Involvement of transforming growth factor-beta in the expression of gicerin, a cell adhesion molecule, in the regeneration of hepatocytes. Int I Mol Med 2007, 3:38I-386.

27. Balzar M, Winter MJ, de Boer CJ, Litvinov SV: The biology of the I7-IA antigen (Ep-CAM). J Mol Med 1999, 10:699-7I2.

28. Mizrak D, Brittan M, Alison MR: CDI33: molecule of the moment. J Pathol 2008, I:3-9.

29. Pagan R, Martin I, Alonso A, Llobera M, Vilaro S: Vimentin filaments follow the preexisting cytokeratin network during epithelial-mesenchymal transition of cultured neonatal rat hepatocytes. Exp Cell Res 1996, 2:333-344.

30. Haussinger D, Lamers WH, Moorman AF: Hepatocyte heterogeneity in the metabolism of amino acids and ammonia. Enzyme 1992, 1-3:72-93.

31. Wang $X$, Willenbring $H$, Akkari $Y$, Torimaru $Y$, Foster M, Al Dhalimy $M$, Lagasse $E$, Finegold $M$, Olson S, Grompe M: Cell fusion is the principal source of bone-marrow-derived hepatocytes. Nature 2003, 422:897-90I.

32. Odom DT, Dowell RD, Jacobsen ES, Nekludova L, Rolfe PA, Danford TW, Gifford DK, Fraenkel E, Bell GI, Young RA: Core transcriptional regulatory circuitry in human hepatocytes. Mol Syst Biol 2006. 2006.0017

33. Dan YY, Riehle KJ, Lazaro C, Teoh N, Haque J, Campbell JS, Fausto $\mathrm{N}$ : Isolation of multipotent progenitor cells from human fetal liver capable of differentiating into liver and mesenchymal lineages. Proc Natl Acad Sci USA 2006, 26:9912-9917.

34. Fukuda J, Okamura K, Ishihara K, Mizumoto $H$, Nakazawa $\mathrm{K}$, ljima $\mathrm{H}$, Kajiwara $T$, Funatsu K: Differentiation effects by the combination of spheroid formation and sodium butyrate treatment in human hepatoblastoma cell line (Hep G2): a possible cell source for hybrid artificial liver. Cell Transplant 2005, 10:819-827.

35. Yamashita T, Ji J, Budhu A, Forgues M, Yang W, Wang HY, Jia H, Ye Q, Qin LX, Wauthier E, Reid LM, Minato H, Honda M, Kaneko S, Tang ZY, Wang XW: EpCAM-Positive Hepatocellular Carcinoma Cells Are Tumor-Initiating Cells With Stem/Progenitor Cell Features. Gastroenterology 2008, 136:1012-1024.

36. Mahieu-Caputo D, Allain JE, Branger J, Coulomb A, Delgado JP, Andreoletti M, Mainot S, Frydman R, Leboulch P, Di Santo JP, Capron F, Weber A: Repopulation of athymic mouse liver by cryopre- served early human fetal hepatoblasts. Hum Gene Ther 2004, 12:1219-1228.

37. Vassilopoulos G, Wang PR, Russell DW: Transplanted bone marrow regenerates liver by cell fusion. Nature 2003, 422:90I-904.

38. Poyck PP, van Wijk AC, Hoeven TV van der, de Waart DR, Chamuleau RA, van Gulik TM, Oude Elferink RP, Hoekstra R: Evaluation of a new immortalized human fetal liver cell line (cBALIII) for application in bioartificial liver. J Hepatol 2008, 2:266-275.

39. Flendrig LM, la Soe JW, Jorning GG, Steenbeek A, Karlsen OT, Bovee WM, Ladiges NC, te Velde AA, Chamuleau RA: In vitro evaluation of a novel bioreactor based on an integral oxygenator and a spirally wound nonwoven polyester matrix for hepatocyte culture as small aggregates. J Hepatol 1997, 6:1379-1392.
Publish with Bio Med Central and every scientist can read your work free of charge

"BioMed Central will be the most significant development for disseminating the results of biomedical research in our lifetime. "

Sir Paul Nurse, Cancer Research UK

Your research papers will be:

- available free of charge to the entire biomedical community

- peer reviewed and published immediately upon acceptance

- cited in PubMed and archived on PubMed Central

- yours - you keep the copyright

Submit your manuscript here:

http://www.biomedcentral.com/info/publishing_adv.asp
BioMedcentral 